\title{
ANALISIS KETERAMPILAN PROSES SAINS MAHASISWA PENDIDIKAN FISIKA DALAM MERANGKAI RANGKAIAN ELEKTRONIKA SEDERHANA
}

\author{
Izkar Hadiya \\ Fakultas Keguruan dan Ilmu Pendidikan, Universitas Malikussaleh \\ e-mail: izkar_hadiya@unimal.ac.id
}

\begin{abstract}
Abstrak :Penelitian ini dilakukan untuk mengukur Keterampilan Proses Sains (KPS) yang merupakan keterampilan penting dalam praktikum pada materi sains. KPS yang tinggi menunjukkan bahwa mahasiswa telah mencapai tujuan pembelajaran yaitu penguasaan konsep yaitu materi elektonika dasar. Penelitian ini menggunakan desain One-Shot Case Study yaitu menerapkan project base learning (PBL) dalam merangkai rangkaian elektronika sederhana. Selanjutnya mengukur KPS mahasiswa berdasarkan soal KPS yang diberikan pada akhir pembelajaran. Purposive sample digunakan adalah mahasiswa fisika yang mengambil Mata kuliah elektronika dasar sebanyak 30 orang. KPS mahasiswa yang diukur meliputi mengidentifikasi variabel, mengungkapkan pengertian variabel, menginterpretasi data, mengklasifikasi data, menghubungkan antar data, memformulasikan model, menarik kesimpulan, dan menyatakan praduga sementara. Hasil penelitian menujukkan bahwa KPS mahasiswa secara keseluruhan $80.0 \pm$ SD 7.886 atau berada dalam kategori baik.
\end{abstract}

\section{Kata Kunci : Keterampilan Proses Sains, Rangkaian elektronika, Project Base Learning \\ ANALYSIS SKILLS OF SCIENTIFIC PROCESS OF STUDENT PHYSICS EDUCATION IN ASSEMBLING SIMPLE ELECTRONICS CIRCUIT}

\begin{abstract}
This research was conducted to measure the Skills of Scientific Process (KPS) which is an important skill in practicum in science material. The high KPS shows that students have achieved the learning objective of mastering the concept of basic electronics materials. This research uses One-Shot Case Study design that is implementing project base learning (PBL) in assembling simple electronics circuit. Next measures the student's KPS based on the KPS question given at the end of the lesson. Purposive samples used are physics students who take basic electronics courses as many as 30 people. Student KPS measurements include identifying variables, expressing the meaning of variables, interpreting data, classifying data, linking data, formulating models, drawing conclusions, and declaring temporary presumptions. The results showed that the overall student KPS $80.0 \pm$ SD 7.886 or are in good category.
\end{abstract}

Keywords: Skills of Scientific Process, Electronic Circuits, Project Base Learning 


\section{PENDAHULUAN}

Elektronika Dasar merupakan mata kuliah wajib bagi mahasiswa program studi pendidikan fisika di Universitas Malikussaleh. Mata kuliah sangat mengedepankan aspek proses. Aspek proses yaitu keterampilan-keterampilan yang akan tumbuh selama proses memperoleh pengetahuan mengenai materi tersebut yaitu salah satunya Keterampilan Proses Sains (KPS).

Hasil pengamatan yang dilakukan dalam kegiatan praktikum dan hasil wawancara yang dilakukan mahasiswa yang mengikuti praktikum elektronika dasar pada umumnya memiliki keterampilan dalam kategori rendah. Nilai tertinggi yaitu secara klasikal berada pada 65,13\% dari standar nilai kelulusan 55 dengan rerata nilai 43,40 \pm SD 32,20. Rendahnya nilai tersebut dapat dikaitkan dengan KPS mahasiswa yang rendah. KPS mahasiswa yang rendah ini dianggap akibat perkuliahan yang hanya menitikberatkan pada penyampaian materi secara langsung tanpa penyertaan mahasiswa dalam proses menemukan konsep atau proses pembelajaran bersifat pasif. Mahasiswa hanya menerima konsep tanpa mengetahui proses lahirnya konsep tersebut. Kondisi ini menyebabkan pencapaian yang diperoleh hanya pada ranah kognitif sedangkan ranah keterampilan (psikomotorik) masih rendah. Keterampilan mahasiswa terbukti rendah didapat dari pengamatan yang dilakukan yaitu ketika mahasiswa tersebut diminta merangkai rangkaian elektronika sederhana, rata-rata mereka masih bingung tentang cara merangkai walaupun telah menerima materi tersebut selama perkuliahan dan mengikuti kegiatan praktikum.

Merangkai rangkaian elektronika bukanlah suatu hal yang dapat dianggap mudah karena boleh jadi mahasiswa mampu merangkai rangkaian yang telah diajarkan tetapi ketika diminta merangkai rangkaian elektronika lainnya mereka sulit mengerjakannya. Oleh karena itu, project base learning (PBL) adalah model pembelajaran yang tepat agar mahasiswa mampu mencapai keterampilan tersebut dengan baik. Project base learning (PBL) adalah pembelajaran berbasis proyek yaitu sebuah model pembelajaran yang menggunakan proyek (kegiatan) sebagai inti pembelajaran. Dalam kegiatan ini, mahasiswa melakukan eksplorasi, penilaian, interpretasi, dan sintesis informasi untuk memperoleh berbagai hasil belajar (pengetahuan, keterampilan, dan sikap). Model pembelajaran ini sangat cocok diterapkan di kalangan perguruan tinggi dikarenakan perkembangan tingkat berpikir mahasiswa sudah sangat berkembang yaitu sudah mampu mencapai tingkat aplikasi, analisis, sintesis, dan evaluasi. Hal ini sesuai dengan pendapat Rais (2010) bahwa tuntutan belajar di perguruan tinggi selain menuntut kemampuan akademik (hard skill), mahasiswa juga dituntut untuk dapat meningkatkan kemampuan personalnya (soft skills), sehingga siap memasuki dunia kerja yang sesungguhnya setelah menyelesaikan studi.

Penelitian Rais (2010) menunjukkan bahwa aktivitas yang terbangun diantara kelompok proyek berlangsung dengan penuh semangat, mahasiswa melalui pengamatan terlihat menikmati cara belajar yang dikembangkan berdasarkan skenario project based learning. Mahasiswa secara kritis mengungkapkan ide-ide dalam kelompok kolaboratif, mulai dari merencanakan sesuatu tentang cara memperoleh pengetahuan, memproses secara kolaboratif dan bermakna, menyimpulkan, hingga saling tukar informasi diantara kelompok sebelum kemudian dilakukan presentase kelompok.

Menurut Rustaman dalam Tasiwan (2015), KPS melibatkan seluruh komponen keterampilan kognitif, manual, dan sosial. Katerampilan kognitif atau intelektual terlibat karena dalam melakukan KPS, mahasiswa menggunakan pikiran dan pengetahuannya. Keterampilan manual dibutuhkan dalam KPS karena melibatkan penggunaan alat dan bahan, pengukuran, penyusunan, atau perakitan alat. Keterampilan sosial dimaksudkan bahwa mereka berinteraksi dengan sesamanya dalam melaksanakan kegiatan belajar mengajar misalnya mendiskusikan hasil pengamatan. KPS merupakan kemampuan dalam mengamati, menginterferensi, mengukur, mengomunikasikan, merumuskan hipotesis, dan melakukan 
eksperimen untuk memperoleh, mengembangkan, dan menerapkan konsep-konsep, prinsipprinsip, hukum-hukum, dan teori-teori.

Ada enam dasar KPS yaitu: 1) pengamatan (observation), 2) komunikasi (communication), 3) pengelompokan (classification), 4) pengukuran (measure-ment), 5) kesimpulan (inference) dan 6) ramalan (prediction) (Sultan, 2014). Indikator KPS yang diukur dalam penelitian ini meliputi mengidentifikasi variabel, mengungkapkan pengertian variabel, menginterpretasi data, mengklasifikasi data, menghubungkan antar data, memformulasikan model, menarik kesimpulan, dan menyatakan praduga sementara. KPS diamati saat kegiatan praktikum.

Keterampilan proses sains bagi seorang mahasiswa sangat diperlukan untuk mempersiapkan diri mereka menghadapi tantangan ke depan yang semakin lama semakin berat. Mereka dituntut memiliki sejumlah keterampilan yang mendukung mereka untuk mendapatkan pekerjaan yang layak yang jumlahnya tidak sesuai dengan banyaknya lulusan yang dihasilkan perguruan tinggi setiap tahunnya. Sehingga oleh karena itu, dengan mengembangkan keterampilan proses sains mahasiswa melalui pembelajaran berbasis proyek ini mahasiswa akan mampu meraih keterampilan-keterampilan lainnya yang mereka butuhkan atau dunia kerja butuhkan.

Pada zaman sekarang, guru bukan hanya dituntut dalam hal kemampuan menyampaikan materi dengan baik tetapi juga harus memiliki beberapa keterampilan untuk diajarkan kepada anak didiknya. Keterampilan proses sains yang dimiliki akan memudahkan guru tersebut dalam menyampaikan ilmu yang dimiliki dengan kegiatan yang menyenangkan bagi siswa. Guru dianggap mampu mengajar dengan baik apabila mampu menghidupkan suasana kelas, menciptakan pembelajaran yang menyenangkan dan meningkatkan keaktifan anak didik. Melalui pembelajaran berbasis keterampilan proses, anak didik akan lebih memahami makna dari pembelajaran yakni pembelajaran juga dapat diperoleh melalui kegiatan proses bukan semata dari sekadar menerima sejumlah teori, prinsip ataupun konsep tetapi juga mengaplikasikannya dalam kehidupan nyata. Pembelajaran juga dapat dilakukan dengan melibatkan diri dalam berbagai kegiatan positif yang dari kegiatan tersebut nantinya akan memberikan mereka pengalaman dan keterampilan proses.

Pada penelitian ini pengalaman belajar mahasiswa didapatkan dari kegiatan merangkai rangkaian elektronika sederhana. Kegiatan ini dimulai dari penyajian materi dalam perkuliahan yang berhubungan dengan teknis merangkai. Mahasiswa diperkenalkan dengan berbagai komponen elektronika dan prinsip penggunaanya, pengukuran arus, tegangan dan hambatan, troubleshooting dalam proses perangkaian dan tatacara merangkai rangkaian pada papan rangkaian. Mahasiswa selanjutnya diberikan tugas (proyek) untuk merangkai rangkaian elektronika sederhana yang dipilih dari beberapa jenis bentuk rangkaian sederhana yang disediakan. Selanjutnya, mahasiswa diminta menggali informasi lebih dalam tentang rangkaian tersebut sebagai tugas proyek dan membuat laporan kegiatan untuk dikomunikasikan hasilnya dalam forum kelas. Pembuatan laporan tersebut mengikuti sistematika penulisan ilmiah dengan berbagai ketentuan tentang isi dari laporan. Selanjutnya dilakukan penilaian menggunakan rubrik penilaian untuk mengukur tingkat keterampilan masing-masing mahasiswa. Selain itu penilaian KPS juga dilakukan melalui pemberian soal tes KPS.

\section{METODE PENELITIAN}

Penelitian ini menggunakan Pre-Eksperimental Design yaitu One-Shot Case Study. KPS diukur setelah penerapan pembelajaran merangkai rangkaian elektronika sederhana. Sampel dalam penelitian ini yaitu mahasiswa pendidikan fisika Universitas Malikussaleh tahun akademik 2015/2016 yaitu berjumlah 30 orang. Pemilihan sampel (purposive sample) dimaksudkan dengan pertimbangan bahwa mahasiswa tersebut telah mengikuti praktikum 
elektronika dasar sebelumnya di Laboratorium Elektronika Dasar Fakultas Teknik Universitas Malikussaleh. Diharapkan dengan dasar tersebut dapat menumbuhkan KPS sebagai keterampilan untuk memahami konsep sains yang akan diperlajari lebih lanjut.

Teknik pengumpulan data KPS mahasiswa diperoleh melalui pemberian tes KPS diakhir pembelajaran. Untuk mengetahui bahwa proses ilmiah itu terjadi dan mahasiswa memahami konsep dengan baik, maka dalam soal tes KPS, mahasiswa dituntut untuk mengemukakan alasan mengapa ia memilih jawaban tersebut, sehingga dapat diinterpretasikan apakah mahasiswa hanya menebak, salah konsep, atau tidak memahami KPS yang diperoleh selama pembelajaran. Pengukuran KPS Mahasiswa setelah perkuliahan Elektronika Dasar merangkai rangkaian elektronika sederhana khususnya pada materi pengenalan komponen elektronika, prinsip dan penggunaan, pengukuran dan tata cara merangkai dilakukan melalui pemberian soal tes KPS berdasarkan tinjauan setiap aspek KPS meliputi mengidentifikasi variabel, mengungkapkan pengertian variabel, menginterpretasi data, mengklasifikasi data menghubungkan antar data, memformulasikan model, menarik kesimpulan, dan menyatakan praduga sementara.

Tabel 1. Sebaran Aspek KPS pada Setiap Indikator Soal

\begin{tabular}{|c|c|c|c|}
\hline No & Indikator Soal & No. Soal & Aspek KPS \\
\hline 1. & $\begin{array}{l}\text { Menyebutkan berbagai } \\
\text { komponen elektronika }\end{array}$ & 1 & 4 \\
\hline 2. & $\begin{array}{l}\text { Mengklasifikasikan } \\
\text { komponen berdasarkan } \\
\text { jenis }\end{array}$ & 2 & $3,4,5$ \\
\hline 3. & 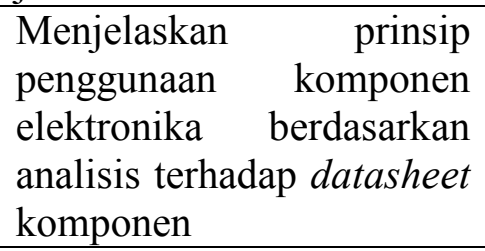 & $\begin{array}{l}3 \\
4 \\
5 \\
6 \\
7\end{array}$ & $\begin{array}{l}1,2,3,4 \\
4,5,6,7 \\
6,7,8 \\
5,8 \\
1,8 \\
\end{array}$ \\
\hline 4. & $\begin{array}{ll}\text { Menganalisis } & \text { rangkaian } \\
\text { elektronika } & \text { sederhana } \\
\text { yang ditugaskan } & \end{array}$ & $\begin{array}{l}8 \\
9\end{array}$ & $\begin{array}{l}1,2 \\
5,6,7,8\end{array}$ \\
\hline 5. & $\begin{array}{lr}\text { Menentukan } & \text { komponen } \\
\text { elektronika yang akan } \\
\text { digunakan } & \text { dengan } \\
\text { menggunakan } & \text { datasheet } \\
\text { komponen } & \\
\end{array}$ & $\begin{array}{l}10 \\
11\end{array}$ & $\begin{array}{l}3,4,5 \\
6,7,8\end{array}$ \\
\hline 6. & \begin{tabular}{lr} 
Merangkai & \multicolumn{2}{c}{ komponen } \\
elektronika & pada papan \\
rangkaian &
\end{tabular} & 12 & $3,5,6,7$ \\
\hline 7. & \begin{tabular}{lr}
$\begin{array}{l}\text { Menguji } \\
\text { rangkaian }\end{array}$ & $\begin{array}{r}\text { ketepatan } \\
\text { elektronika } \\
\text { dengan } \\
\text { skema }\end{array}$ \\
datasheet & komperhatikan \\
hasil rangkaian, & \multicolumn{2}{c}{ pengukuran } \\
tegangan, hambatan dan \\
arus serta kinerja \\
rangkaian
\end{tabular} & $\begin{array}{l}13 \\
14 \\
15 \\
16\end{array}$ & $\begin{array}{l}3,5,6,7 \\
7,8 \\
1,2,6 \\
7,8\end{array}$ \\
\hline 8. & Menemukan & 17 & $5,7,8$ \\
\hline
\end{tabular}




\begin{tabular}{|c|c|c|c|}
\hline & $\begin{array}{l}\text { troubleshooting dalam } \\
\text { rangkaian elektronika }\end{array}$ & 18 & 7 \\
\hline 9. & $\begin{array}{l}\text { Memperbaiki dan } \\
\text { menghilangkan } \\
\text { troubleshooting }\end{array}$ & 19 & $3,4,5,7$ \\
\hline 10. & $\begin{array}{l}\text { Mempresentasikan } \\
\text { rangkaian di forum kelas }\end{array}$ & 20 & $2,3,4,5,6,7,8$ \\
\hline
\end{tabular}

Tabel 3. Aspek Indikator KPS

\begin{tabular}{|l|l|}
\hline \multicolumn{1}{|c|}{ Keterangan } \\
\hline $\begin{array}{l}\text { Indikator } \\
\text { Pengamatan } \\
\text { Observation })\end{array}$ & 1. Mengidentifikasi variabel \\
\hline $\begin{array}{l}\text { Komunikasi } \\
(\text { Communication })\end{array}$ & $\begin{array}{l}\text { 2. Mengungkapkan variable } \\
\text { 3. Menginterpretasikan data }\end{array}$ \\
\hline $\begin{array}{l}\text { Pengelompokan } \\
\text { (Clasification) }\end{array}$ & $\begin{array}{l}\text { 4. Mengklasifikasikan data } \\
\text { 5. Menghubungkan antar data }\end{array}$ \\
\hline $\begin{array}{l}\text { Pengukuran } \\
\text { (Measurement })\end{array}$ & 6. Memformulasikan model \\
\hline $\begin{array}{l}\text { Kesimpulan } \\
\text { (Inference })\end{array}$ & 7. Menarik Kesimpulan \\
\hline $\begin{array}{l}\text { Ramalan } \\
\text { (Prediction) }\end{array}$ & 8. Menyatakan praduga sementara \\
\hline
\end{tabular}

Sumber :Widyaningsih dan Irfan (2016)

Selanjutnya menginterpretasikan hasil penilaian untuk setiap pernyataan dengan kriteria berikut ini :

Tabel 4. Kriteria Interpretasi Skor

\begin{tabular}{|l|l|}
\hline Persentase (\%) & Kriteria \\
\hline $0-25$ & Sangat Kurang \\
\hline $26-50$ & Kurang \\
\hline $51-75$ & Baik \\
\hline $76-100$ & Sangat Baik \\
\hline
\end{tabular}

Sumber : Riduwan dalam Widyaningsih dan Irfan (2016)

Hasil interpretasi tersebut kemudian dihitung rerata persentase KPS yang diperoleh.

\section{HASIL DAN PEMBAHASAN}

Hasil penelitian menunjukkan bahwa rerata persentase KPS mahasiswa setelah belajar merangkai rangkaian elektronika dengan model Project Base Learning (PBL) berada dalam kategori sangat baik.

Tabel 5. Persentase (\%) KPS untuk setiap Indikator

\begin{tabular}{|l|l|l|c|}
\hline Indikator & $\%$ & SD & Kategori \\
\hline Menyebutkan berbagai komponen & 85 & 5.76 & Sangat \\
\hline
\end{tabular}




\begin{tabular}{|c|c|c|c|}
\hline elektronika & & & baik \\
\hline $\begin{array}{l}\text { Mengklasifikasikan } \\
\text { berdasarkan jenis }\end{array}$ & 75 & 8.3 & Baik \\
\hline $\begin{array}{l}\text { Menjelaskan prinsip penggunaan } \\
\text { komponen elektronika }\end{array}$ & 70 & 11.6 & Baik \\
\hline 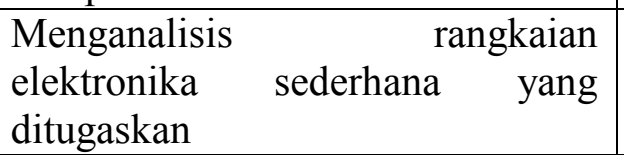 & 80 & 4.7 & $\begin{array}{l}\text { Sangat } \\
\text { baik }\end{array}$ \\
\hline $\begin{array}{l}\text { Menentukan } \\
\text { elektronika yang akan digunakan }\end{array}$ & 80 & 4.3 & $\begin{array}{l}\text { Sangat } \\
\text { baik }\end{array}$ \\
\hline $\begin{array}{l}\text { Merangkai komponen elektronika } \\
\text { pada papan rangkaian }\end{array}$ & 75 & 4.8 & baik \\
\hline $\begin{array}{l}\text { Menguji ketepatan rangkaian } \\
\text { elektronika }\end{array}$ & 80 & 5.5 & $\begin{array}{c}\text { Sangat } \\
\text { baik }\end{array}$ \\
\hline $\begin{array}{l}\text { Menemukan troubleshooting dalam } \\
\text { rangkaian elektronika }\end{array}$ & 85 & 11.8 & $\begin{array}{c}\text { Sangat } \\
\text { baik }\end{array}$ \\
\hline $\begin{array}{l}\text { Memperbaiki dan menghilangkan } \\
\text { troubleshooting }\end{array}$ & 90 & 12.5 & $\begin{array}{c}\text { Sangat } \\
\text { baik }\end{array}$ \\
\hline $\begin{array}{l}\text { Mempresentasikan rangkaian di } \\
\text { forum kelas }\end{array}$ & 80 & 9.6 & $\begin{array}{c}\text { Sangat } \\
\text { baik }\end{array}$ \\
\hline Rerata & 80 & 7.88 & $\begin{array}{c}\text { Sangat } \\
\text { baik }\end{array}$ \\
\hline
\end{tabular}

Berdasarkan hasil analisis KPS pada setiap indikator keterampilan pada Tabel 5 terlihat bahwa KPS mahasiswa sangat baik. Salah satu penyebabnya yaitu model pembelajaran Project Base Learning (PBL). Mahasiswa menyelidiki ide-ide penting dan bertanya, menemukan pemahaman dalam proses menyelidiki, menghasilkan produk dan berpikir kreatif, kritis dan terampil menyelidiki, menyimpulkan materi, serta menghubungkan dengan masalah dunia nyata, otentik dan isu-isu. Mahasiswa juga merencanakan dan melaksanakan penyelidikan terhadap beberapa topik atau tema yang menggunakan lintas mata pelajaran atau lintas materi. Pembelajaran berbasis proyek merupakan metode belajar yang menggunakan masalah sebagai langkah awal dalam mengumpulkan dan mengintegrasikan pengetahuan baru berdasarkan pengalamannya dalam beraktivitas secara nyata. Melalui pembelajaran berbasis proyek, proses inquiry dimulai dengan memunculkan pertanyaan penuntun (a guiding question) dan membimbing peserta didik dalam sebuah proyek kolaboratif yang mengintegrasikan berbagai subjek (materi) dalam kurikulum dan menemukan hubungan berbagai prinsip dalam sebuah disiplin yang sedang dikajinya. Kegiatan merangkai rangkaian elektronika ini juga dimulai dari membangun ide tentang rangkaian elektronika apa yang sebaiknya dibuat, bagaimana proses pengerjaannya, siapa saja pihak yang akan diminta membantu dalam proses pengerjaan, berapa dana yang harus dikeluarkan, apa yang dilakukan seandainya timbul permasalahan dan sebagainya. Pembuatan proyek ini bersifat penugasan terstruktur yang dipandu atau diarahkan melaui sejumlah pertanyaan dan batasan. Batasan ini diperlukan agar penyelesaian proyek dapat diselesaikan sesuai dengan waktu yang tersedia. Waktu pengerjaan dibatasi selama 2 bulan dengan dana yang dikeluarkan tidak boleh lebih dari Rp. 200.000 per kelompok. Hal ini diperlukan untuk mencegah timbulnya kesenjangan dari setiap kelompok. Produk yang dihasilkan juga dinilai kualitasnya berdasarkan kinerja, kemenarikan produk, efisiensi, efektifitas dan dana yang dikeluarkan untuk produk yang dimaksud.

Selain itu proyek yang diberikan memuat tugas-tugas yang kompleks berdasarkan permasalahan (problem) sebagai langkah awal dalam mengumpulkan dan mengintegrasikan 
pengetahuan baru berdasarkan pengalamannya dalam beraktivitas secara nyata dan menuntut siswa untuk melakukan kegiatan merancang, memecahkan masalah, membuat keputusan, melakukan kegiatan investigasi, serta memberikan kesempatan siswa untuk bekerja secara mandiri maupun kelompok. Hasil akhir dari kerja proyek tersebut adalah suatu produk yang antara lain berupa laporan tertulis atau lisan, presentasi atau rekomendasi.

Penelitian Rais (2010) menunjukkan bahwa aktivitas yang terbangun diantara kelompok proyek berlangsung dengan penuh semangat, mahasiswa melalui pengamatan terlihat menikmati cara belajar yang dikembangkan berdasarkan skenario project based learning. Mahasiswa secara kritis mengungkapkan ide-ide dalam kelompok kolaboratif, mulai dari merencanakan sesuatu tentang cara memperoleh pengetahuan, memproses secara kolaboratif dan bermakna, menyimpulkan, hingga saling tukar informasi diantara kelompok sebelum kemudian dilakukan presentasi kelompok.

Dalam penelitian ini pembelajaran dilaksanakan secara berkelompok karena sangat sulit bagi mereka bila dilakukan secara perorangan. Pembelajaran secara berkelompok ini dilakukan untuk mengkolaborasi ide, mulai dari perencanaan, pengerjaan, pembuatan laporan sampai dengan presentasi rangkaian. Penilaian pun dilakukan secara berkelompok sehingga setiap anggota kelompok akan berusaha untuk memberikan perhatiannya dalam bentuk ide, dana maupun tenaga untuk mendukung keberhasilan proyek yang dikerjakan. Presentasi yang dilakukan pun bersifat kolektif karena semua anggota kelompok harus hadir dan menyampaikan tentang ide dari proyek yang dilaksanakan.

Project-based learning berfokus pada konsep-konsep dan prinsip-prinsip utama (central) dari suatu disiplin, melibatkan mahasiswa dalam kegiatan pemecahan masalah dan tugas-tugas bermakna lainya, memberi peluang mahasiswa bekerja secara otonom mengkonstruk belajar mereka sendiri, dan puncaknya menghasilkan produk karya mahasiswa bernilai, dan realistik (Okudan. Gul E. dan Sarah E. Rzasa, 2004). Seperti halnya dalam kegiatan penelitian ini, mahasiswa diminta memanfaatkan konsep-konsep, prinsip-prinsip elektronika dalam persoalan troubleshooting rangkaian elektronika sehingga diperoleh pengalaman belajar yang membantu siswa mengkonstruk pembelajaran mandiri yakni pengalaman belajar mereka sendiri. Dari pembelajaran mandiri ini selanjutnya mahasiswa mampu menghasilkan karya yang bernilai dan realistik yakni rangkaian elektronika sederhana.

Pembelajaran berbasis proyek menurut Thomas (2000) berfokus pada konsep-konsep dan prinsip-prinsip inti dari suatu disiplin studi, melibatkan mahasiswa dalam investigasi pemecahan masalah dan kegiatan tugas-tugas bermakna yang lain, memberi kesempatan mahasiswa bekerja secara otonom mengkonstruk pengetahuan mereka sendiri, dan mencapai puncaknya menghasilkan produk nyata. Sehingga pembelajaran ini sangat signifikan dalam mengembangkan KPS mahasiswa. Mahasiswa mampu mengidentifikasi variabel dengan baik yaitu komponen yang dibutuhkan dalam rangkaian berdasarkan pengetahuan sebelumnya, menyebutkan nama dan spesifikasinya, menjelaskan fungsinya, mengklasifikasikan bagian dari rangkaian yaitu bagian input, proses dan outputnya, menghubungkan pengetahuan sebelumnya dengan proses menyelesaikan troubleshooting dalam rangkaian, memperbaiki bentuk rangkaian dan memformulasikan sebagai model rangkaian yang baku serta melakukan pengembangan, menarik kesimpulan dari troubleshooting yang diperoleh tentang cara merangkai yang baik dan benar dan menyatakan kesimpulan tersebut dalam forum kelas sebagai praduga sementara yang nantinya akan diuji saat mahasiswa dihadapkan dengan rangkaian elektronika lainnya.

Rosenfeld (2001) menyebutkan bahwa pembelajaran melalui PBL ini meliputi : (1) membuat pertanyaan yang akan dijadikan proyek, (2) memilih pertanyaan utama atau menentukan proyek, (3) membaca dan mencari materi yang relevan dengan masalah, (4) merancang masalah, (5) merancang/ metode yang tepat dalam memecahkan masalah, (6) 
menulis proyek proposal, (7) implementasi dan membuat dokumen tugas, (8) analisis data dan membuat simpulan, (9) membuat laporan final, (10) mempresentasikan proyek final. Tahapan-tahapan tersebut akan membiasakan mahasiswa dengan proses sains sehingga akan meningkatkan keterampilannya.

Dalam menentukan proyek yang diselesaikan mahasiswa diberikan pilihan untuk memilih salah satu. Penyelesaian proyek diberikan tenggat waktu yang sama untuk setiap proyek yang dipilih dan diselesaikan secara berkelompok. Mahasiswa diberi kesempatan untuk belajar di lapangan dengan teknisi alat elektronika atau melalui tutorial berupa video yang dapat diunduh dari internet. Proses menemukan informasi dari berbagai sumber secara mandiri ini akan meningkatkan keterampilan mahasiswa dalam menggali informasi, menginterpretasi dan menghubungkan data untuk dapat menarik suatu kesimpulan yang akan membantu mereka dalam penyelesaian proyek. Dalam proses merangkai rangkaian elektronika, mahasiswa memperoleh sejumlah permasalahan yang selanjutnya diidentifikasi dan dirancang sedemikian rupa sehingga menjadi suatu persoalan yang kompleks yang membutuhkan metode khusus untuk menyelesaikannya. Metode penyelesaian harus dipilih metode yang bersifat khusus sehingga proyek yang dibuat tersebut berdaya guna. Mahasiswa selanjutnya diminta menulis proyek proposal yang berisi latar belakang pemilihan proyek, bentuk rangkaian elekronika yang akan dicoba rangkai, langkah pengerjaan, rincian anggaran yang digunakan, permasalahan yang mungkin timbul dan cara mengatasinya. Setelah itu dilakukan proses pengerjaan proyek dan membuat laporan. Dalam proses pengerjaan dilakukan proses analisis terhadap troubleshooting dalam rangkaian dan kesimpulan terhadap troubleshooting tersebut.Selanjutnya mahasiswa diminta membuat laporan final dan mempresentasikannya. Pengerjaan proyek dilakukan secara berkelompok dilakukan untuk membiasakan mahasiswa bekerja dalam kelompok dan menjadikan mahasiswa tersebut lebih termotivasi dalam pengerjaan proyek.

Mahasiswa yang terlibat dalam pengerjaan proyek telah dibekali dengan sejumlah teori melalui perkuliahan, yang selanjutnya teori tersebut akan dipraktekkan dalam penyelesaian tugas proyek yang diberikan. Hal ini sejalan dengan Sukarno, dkk (2013) bahwa pengajar perlu mengembangkan perangkat pembelajaran sains yang baik sehingga dapat mengembangkan KPS peserta didik.

Berdasarkan analisis pada setiap indikator KPS diperoleh bahwa mahasiswa memperoleh sebaran nilai KPS yang sangat baik pada setiap aspek KPS. Sebagian besar mahasiswa memiliki kemampuan yang baik dalam menyelesaikan soal KPS yang diberikan pada akhir pembelajaran. Nilai rerata KPS tertinggi didapatkan untuk aspek KPS yaitu menginterpretasikan data yakni mahasiswa mampu dengan baik memanfaatkan data yang ada untuk penyelesaian masalah yang didapatkan dalam proses merangkai rangkaian elektronika sederhana tersebut. Nilai rerata aspek KPS terendah adalah pada aspek mengklasifikasikan data. Dalam hal ini mahasiswa belum cukup mampu memilah antara data yang diperlukan dan yang tidak diperlukan. Mahasiswa banyak membuang waktu dan tenaga untuk mencari sejumlah infomasi yang dianggap dibutuhkan sehingga pengerjaan proyek kurang efisien. Hal ini wajar disebabkan mahasiswa sedang berusaha mengembangkan kemandirian dalam belajar seperti yang disebutkan Rais, dkk (2009) dalam penelitian. Sedangkan untuk aspek lainnya semua berkembang dengan baik. 


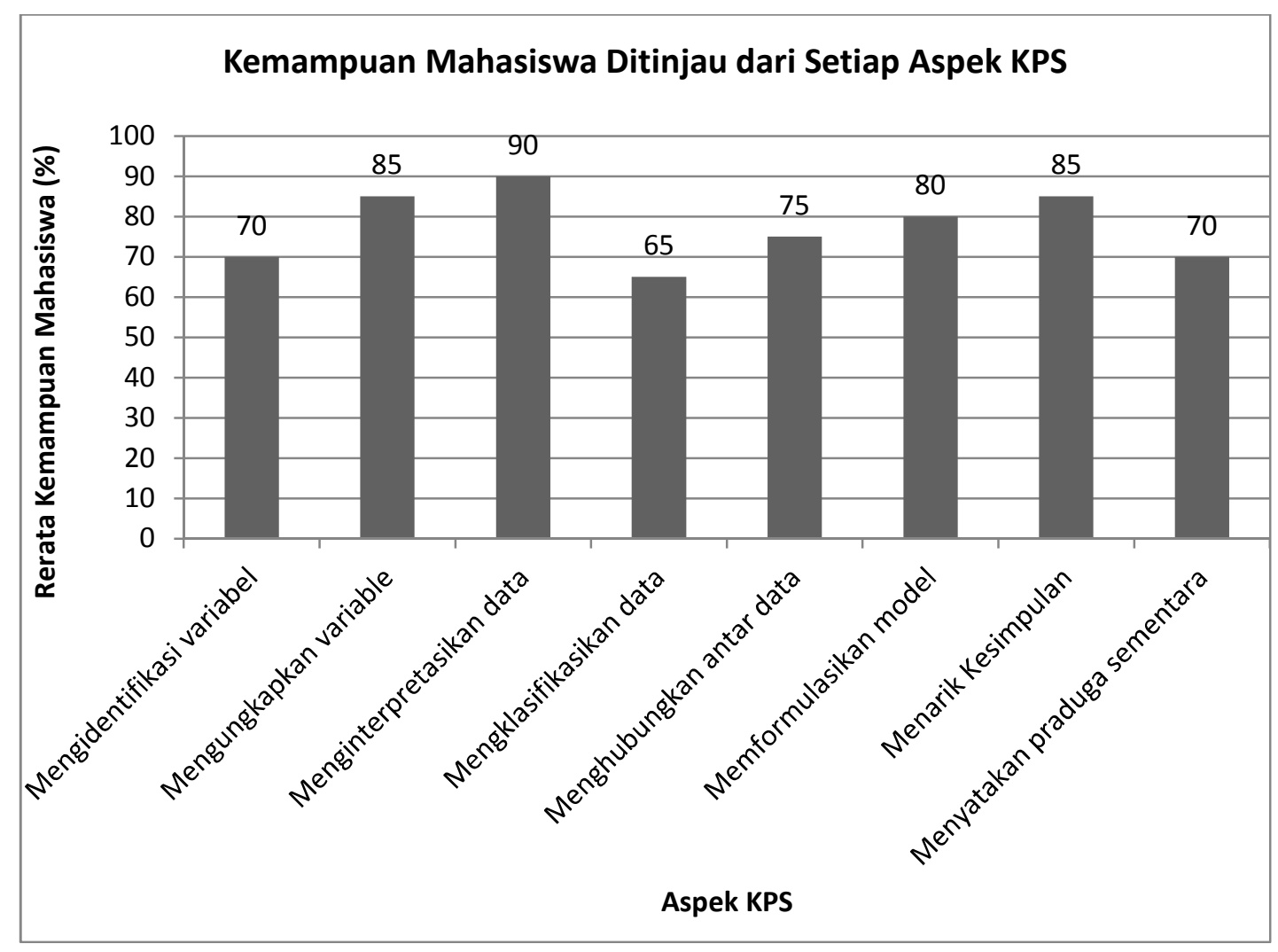

Gambar 1. Kemampuan Mahasiswa Ditinjau dari Setiap Aspek KPS

Aspek KPS yang diperoleh pada persentase yang sangat baik menunjukkan bahwa pembelajaran dengan project base learning berhasil meningkatkan keterampilan proses sains mahasiswa pada umumnya.

Hasil penelitian yang dilakukan oleh Rais, dkk (2009), terkait dengan model pengembangan strategi project-based learning dalam upaya menumbuhkan sikap kemandirian belajar mahasiswa, motivasi belajar mahasiswa, dan kemampuan pemecahan masalah yang direpresentasikan sebagai kecakapan akademik umumnya memiliki nilai skor mean pre test yaitu sebesar 62,3 dan mean skor post testnya adalah sebesar 81,58. Perbedaan nilai skor ini menunjukkan peningkatan yang cukup signifikan.

Kegiatan pembelajaran berupa merangkai rangkaian elektronika sederhana selain mampu meningkatkan KPS mahasiswa, juga menimbulkan kemandirian belajar, motivasi belajar dan kemampuan pemecahan masalah. Berdasarkan hasil pengamatan dan wawancara dengan mahasiswa yang menjadi sampel penelitian ini, mereka menyenangi proses pembelajaran yang berlangsung karena pembelajaran lebih menarik disebabkan mereka dapat menerapkan pengetahuan berupa teori dalam praktek. Setiap kegiatan yang dilaksanakan menjadi berguna karena menambah pengetahuan, keterampilan dan sikap ilmiah. Semua mahasiswa berlomba menunjukkan hasil terbaik dengan selalu mencari informasi baru dengan bertanya, membuka literasi, terus mencoba yang akhirnya meningkatkan kreativitas dan pemikiran kritis dan logis. Mahasiswa juga mampu mengembangkan kreatifitasnya dalam membuat sejumlah rangkaian elektronika. Terdapat sejumlah ide menarik yang timbul di kalangan mahasiswa untuk menciptakan rangkaian-rangkaian elektronika yang lebih berguna dan mampu dipasarkan. Mereka termotivasi untuk menciptakan rangkaian-rangkaian elektronika berikutnya yang lebih mengesankan. 
Mahasiswa dalam kegiatan pembelajaran ini telah mampu merangkai beberapa rangkaian elektronika yaitu rangkaian elektronika alarm anti maling, rangkaian elektronika alat pijat sederhana, rangkaian elektronika detektor hujan sederhana, rangkaian flip-flop, rangkaian timer sederhana, rangkaian led kedap-kedip dan rangkaian regulator tegangan.

Banyak hal menarik yang diperoleh selama proses pembelajaran. Mahasiswa sangat terkesan dengan hasil kerja mereka terutama ketika rangkaian yang mereka buat bekerja dengan baik. Rangkaian elektronika yang dibuat untuk jenis yang sama masing-masing dibuat dalam dua variasi. Mereka merangkai dengan mencoba merangkai komponen elektronika sesuai dengan bentuk rangkaian elektronika yang diambil contoh dari internet. Awalnya mereka pesimis bahwa rangkaian elektronika tersebut dapat bekerja dengan baik, tetapi setelah dicoba merangkai ternyata rangkaian tersebut berfungsi sesuai dengan yang diharapkan yang selanjutnya makin memicu semangat mereka untuk mencoba merangkai rangkaian elektronika lainnya. Semangat ini semakin timbul setelah mendapatkan motivasi untuk meningkatkan kemampuan mereka khususnya dalam pengembangan produk sehingga suatu saat bisa bersaing di pasaran nasional setidaknya. Kemampuan ini perlu terus dilatih karena tanpa latihan kemampuan ini suatu saat bisa menghilang dengan sendirinya. Mahasiswa diminta terus mengembangkan kemampuan karena suatu saat mereka akan menjadi pendidik yang akan mengajarkan anak didiknya tentang pengetahuan dan keterampilan. Keterampilan ini tentunya akan sangat berguna ketika mereka menjadi pendidik, karena ada hal baik dan berguna yang mampu mereka ajarkan kepada anak didiknya.

Keterampilan merangkai elektronika ini sangat penting untuk dikembangkan karena pada kurikulum 2013 terdapat mata pelajaran prakarya yang menuntut pendidik mampu mengajarkan keterampilan yang sesuai dengan bidang studi mereka. Merangkai rangkaian elektronika memiliki hubungan yang sangat erat dengan bidang studi kajian fisika disebabkan merangkai rangkaian elektronika ini membutuhkan pemahaman tentang konsep listrik dinamis. Konsep listrik dinamis akan hanya akan menjadi sekedar konsep fisika yang cukup diketahui dan dipahami tentang prinsip-prinsipnya tanpa pernah menyentuh bagian aplikasi, analisis, sintesis maupu evaluasi. Melalui praktikum merangkai rangkaian elektronika ini akan diperoleh gambaran yang lebih baik tentang mata pelajaran fisika sehingga anggapan bahwa fisika adalah mata pelajaran yang hanya mengedepankan penggunaan rumus fisika untuk menyelesaikan berbagai soal fisika dan merupakan mata pelajaran yang tidak disenangi bisa diminimalisir sehingga menjadi mata pelajaran yang menyenangkan.

Gambar 2 di bawah ini adalah foto rangkaian led kedap-kedip yang mampu diselesaikan mahasiswa. Banyak pihak yang mungkin menganggap hal ini tidak mengesankan karena keterampilan ini juga bisa saja dimiliki oleh orang-orang tanpa perlu mengikuti bangku perkuliahan tetapi keterampilan yang diperoleh ini bersifat keilmuan karena mahasiswa akan lebih mampu menjelaskan tentang sistem kerja dari rangkaian yang mereka buat dibandingkan teknisi pada umumnya. Mahasiswa mampu menghubungkan sejumlah konsep yang mereka pelajari dalam menyelesaikan troubleshooting sehingga diperoleh rangkaian elektronika yang sesuai dengan fungsinya. Mahasiswa juga mampu melakukan pengembangan terhadap rangkaian yang ada sehingga menjadi lebih menarik. Keterampilan ini akan semakin baik bila terus dilatih sehingga suatu saat mereka dapat memperbaiki berbagai alat elektronika yang ada. Persaingan dunia kerja yang terus meningkat akan semakin menuntut lulusan perguruan tinggi memiliki kemampuan khusus yang lebih baik dibandingkan lulusan perguruan tinggi lainnya. Keterampilan ini akan mendukung mahasiswa untuk dapat meraih impian mereka.

Banyak dari kalangan masyarakat yang masih menganggap remeh lulusan fakultas keguruan dan ilmu pendidikan. Bahkan ada yang menyepelekan profesi guru disebabkan guru di lapangan kurang mampu mengembangkan keterampilan anak didiknya. Lulusan sekolah 
menengah tidak memiliki keterampilan khusus yang bermakna. Mereka hanya memiliki sejumlah pengetahuan yang kurang mampu diaplikasikan dalam kehidupan nyata. Sehingga sekolah hanya semata untuk mendapatkan ijazah tanpa output pembelajaran yang berarti dan berbekas di benak siswa. Hal ini dapat dibuktikan dari sejumlah mahasiswa yang ternyata setelah menamatkan sekolah dan melanjutkan ke perguruan tinggi mereka kurang mampu menginterpretasikan ilmu yang mereka pelajari di sekolah dikarenakan pembelajaran yang diberikan kurang member kesan sehingga hanya sedikit yang membekas di benak mereka.

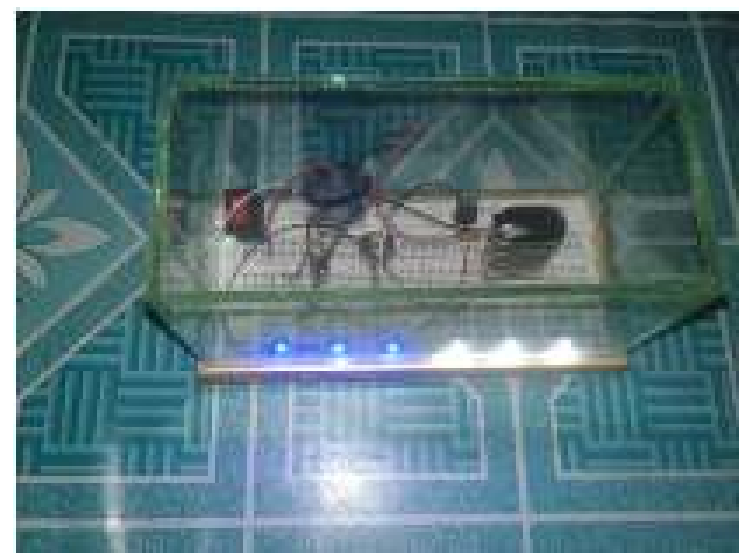

Gambar 2. Rangkaian Led Kedap-Kedip Sederhana Hasil Kerja Mahasiswa

Pengembangan keterampilan proses sains (KPS) sangat penting dilakukan dikarenakan Menurut Trianto (2010) dalam Yennita (2012) keterampilan proses perlu dilatih dan dikembangkan dalam pengajaran IPA (termasuk Fisika Dasar) karena keterampilan proses mempunyai peran-peran sebagai berikut yaitu membantu mahasiswa belajar mengembangkan pikirannya, memberi kesempatan kepada mahasiswa untuk melakukan penemuan, meningkatkan daya ingat dan memberikan kepuasan instrinsik bila telah berhasil melakukan sesuatu. Selain itu menurut Yennita (2012) keterampilan proses sains dapat membantu mahasiswa mempelajari konsep-konsep sains (Yennita, 2012:2).

Keterampilan proses sains (KPS) mahasiswa yang baik yang diperoleh dalam pembelajaran berbasis proyek ini seperti disebutkan Yennita (2012) akan mampu digunakan mahasiswa untuk mempelajari konsep-konsep sains lainnya sehingga mahasiswa tersebut tidak lagi mengalami kesulitan belajar seperti sebelumnya yang hanya menunggu dipandu oleh pengajar tetapi mereka dapat mempelajari sendiri berbagai ilmu yang ingin mereka pelajari. Hal ini tentunya akan sangat didukung oleh perkembangan teknologi informasi zaman sekarang. Pada zaman ini mahasiswa dapat mengakses sumber pengetahuan dari berbagai media yang ada tidak hanya terbatas pada keberadaan buku penunjang. Pembelajaran tidak lagi terpaku oleh ada tidaknya pengajar tetapi pembelajaran dapat dilakukan dimanapun dan kapanpun. Pengajar hanya memandu proses pembelajaran agar tidak keluar dari konteks yang dipelajari sehingga masih sesuai dengan ranah objek kajian. Selain itu pengajar menjadi evaluator yang mengevaluasi proses dan hasil pembelajaran yang dilakukan. Belajar sebagaimana yang diketahui adalah tanggung jawab anak didik sepenuhnya dan bukanlah beban yang harus disandangkan di bahu para pendidik dan pengajar bila tidak mencapai target yang diharapkan. Keberhasilan utama dari proses pembelajaran ditentukan hampir sepenuhnya oleh pihak yang belajar itu sendiri sedangkan yang lainnya hanya sebagai pendukung.

Prilianti (2014) menambahkan bahwa Ilmu Pengetahuan Alam merupakan pengetahuan yang diperoleh melalui pengumpulan data dengan eksperimen, pengamatan, dan deduksi untuk menghasilkan suatu penjelasan tentang sebuah gejala yang dapat dipercaya. Penerapan pendekatan saintifik dalam pembelajaran melibatkan keterampilan proses seperti 
mengamati, mengklasifikasi, mengukur, meramalkan, menjelaskan, dan menyimpulkan. Pembelajaran IPA lebih menekankan pada penerapan keterampilan proses.

Menurut Lepiyanto (2014), untuk mengembangkan semua keterampilan proses sains dalam perkuliahan biologi (IPA) tentu perlu dikembangkan pembelajaran yang sesuai dengan cara berpikir IPA. Sehingga pembelajaran elektronika dasar juga harus dikembangkan sesuai cara berpikir IPA yaitu dengan merangkai rangkaian elektronika dasar yang terbukti mampu meningkatkan keterampilan proses sains baik menurut teori dan praktek bahkan hasilnya jauh lebih baik dari Laboratorium Virtual yaitu hanya mencapai rerata KPS sebesar 70,9 \pm SD 11,6 atau berada dalam kategori baik dalam penelitian Widyaningsih dan Irfan (2016).Bukan lagi saatnya di mana pembelajaran IPA diajarkan melalui ceramah tetapi pembelajaran IPA sudah saatnya diarahkan untuk mengikuti kegiatan pembelajaran yang mampu meningkatkan keterampilan proses sains mereka yaitu salah satunya melalui pembelajaran berbasis proyek (Project base learning).

Walaupun demikian, model pembelajaran ini sulit dijadikan pilihan utama bagi kalangan pengajar baik tingkat sekolah menengah maupun perguruan tinggi dikarenakan membutuhkan dana yang cukup menguras isi kantong khususnya untuk membeli alat dan bahan praktikum karena praktikum yang dilaksanakan berbeda dengan praktikum pada umumnya karena praktikum dilaksanakan di luar dari judul praktikum yang tersedia di laboratorium sehingga membutuhkan pengadaan sejumlah alat dan bahan yang belum tersedia. Selain itu kadang bahan yang dibutuhkan tidak dijual di pasaran sehingga harus dipesan yang tentunya membutuhkan tambahan waktu dalam pengerjaan apalagi bila terjadi kesalahan dalam merangkai. Teknik penilaian keterampilan juga cukup sulit karena harus membuat beberapa rubrik penilaian untuk menilai peningkatan keterampilan yang dimiliki mahasiswa seluruhnya. Tetapi mengingat output yang mungkin dicapai, kesulitan ini tidak akan melemahkan semangat. Karena pembelajaran ini sangat menarik bagi mahasiswa yang sangat antusias dalam kegiatan pembelajaran juga mahasiswa yang tidak tertarik dengan pembelajaran selama ini.

Peningkatan keterampilan proses sains ini akan sangat membantu mahasiswa dalam pengembangan diri untuk menjadi lulusan yang professional, berintegritas dan bertakwa. Hal ini dikarenakan keterampilan proses sains yang diperoleh melalui pembelajaran berbasis proyek akan mampu memudahkan mahasiswa mempelajari keterampilan lainnya yang mereka butuhkan. Keterampilan proses sains adalah jembatan untuk meraih ilmu pengetahuan. Hal ini dikarenakan pengalaman akan mampu menumbuhkan keterampilan. Pengalaman diperoleh melalui keikutsertaan. Tidak akan ada keterampilan yang diperoleh hanya dari kegiatan mendengarkan pengalaman orang lain. Keterampilan diperoleh melalui pengalaman pribadi. Pembelajaran yang baik tentunya pembelajaran yang menimbulkan kesan bagi mahasiswa. Tidak ada kesan yang mengenang apabila tidak ada organ motorik yang dilibatkan. Mahasiswa tidak pernah melihat, mendengar dan merasakan serta bersentuhan dengan objek tersebut maka tidak akan ada kesan yang didapat.

\section{PENUTUP}

Berdasarkan hasil penelitian diperoleh bahwa KPS mahasiswa yang diukur di ahkir pembelajaran yaitu $80.0 \pm$ SD 7.886 atau berada dalam kategori sangat baik. Pembelajaran merangkai rangkaian elektronika sederhana sangat efektif digunakan dalam mengembangkan KPS mahasiswa. Mahasiswa dapat mengidentifikasi variabel, mengungkapkan pengertian variabel, menginterpretasi data, mengklasifikasi data, menghubungkan antar data, memformulasikan model, menarik kesimpulan, dan menyatakan praduga sementara.

Berdasarkan hasil yang diperoleh pada penelitian ini maka dapat disarankan bahwa pembelajaran dengan project base learning melalui kegiatan praktikum dengan alat dan bahan sederhana seperti merangkai rangkaian elektronika sederhana dapat menjadi alternatif 
yang tepat dalam proses pembelajaran elektronika dasar khususnya untuk menumbuhkan KPS mahasiswa terutama jika ingin meningkatkan ketertarikan mahasiswa terhadap mata kuliah ini disebabkan mata kuliah ini sedikit sulit diajarkan bila tanpa praktek langsung.

Selain itu pembelajaran seperti ini juga penting untuk membiasakan mahasiswa dengan pembelajaran aktif sehingga mereka dapat menemukan makna dari pembelajaran. Keterampilan proses sains yang tumbuh di kalangan mahasiswa ini suatu saat diharapkan akan menumbuhkan sejumlah keterampilan lainnya yang dibutuhkan mereka dalam dunia kerja. Belajar bukanlah aktivitas yang menjemukan tetapi belajar dapat menjadi andalan bagi mereka untuk menyongsong masa depan yang lebih baik. Mahasiswa adalah calon pembawa panji perubahan Negara ke arah masa kejayaan.

Penelitian selanjutnya diharapkan akan lebih banyak penelitian yang menitikberatkan pada peningkatan keterampilan proses sains mahasiswa. Bukan hanya dalam jumlah tetapi juga dalam kuantitas. Selain itu juga dilakukan dalam berbagai bentuk pendekatan saintifik dalam kegiatannya sesuai dengan tuntutan kurikulum saat ini.

\section{UCAPAN TERIMA KASIH}

Ucapan terimakasih tidak lupa diucapkan kepada semua pihak yang terlibat dalam penelitian ini, yakni mahasiswa/mahasiswi yang mengikuti kegiatan perkuliahan/penelitian ini, rekanrekan sejawat yang telah memberikan motivasi, keluarga yang ikut memberikan dorongan moril (dukungan), terkhusus ucapan terimakasih ditujukan kepada narasumber yang menjadi rujukan penulis, dan proofread yang telah membantu dalam proses penulisan.

\section{DAFTAR PUSTAKA}

Lepiyanto, A. (2014). Analisis Keterampilan Proses Sains Pada Pembelajaran Berbasis Praktikum. BIOEDUKASI. Jurnal Pendidikan Biologi Universitas Muhammadiyah Metro. Vol 5. No 2. Hal. 157.

Okudan. Gul E. dan Sarah E. Rzasa. 2004. A Project-Based Approach to Entreprenurial Leadership Education. Journal Technovation. Desember. Volume XX. Page 1-16.

Prilianti, R. 2014. Ketrampilan Proses Sebagai Penerapan Pendekatan Scientific Dalam Pembelajaran IPA . http://bdksemarang.kemenag.go.id.

Rais. (2009). Pengembangan Model Project Based Learning: Suatu Upaya Meningkatkan Kecakapan Akademik Mahasiswa Jurusan Teknik Mesin UNM.Laporan Penelitian Tahun I DP2M DIKTI-LEMLIT UNM.

Rais. (2010). Pengembangan Model Project Based Learning: Suatu Upaya Meningkatkan Kecakapan Akademik Mahasiswa Jurusan Teknik Mesin UNM.Laporan Penelitian Tahun II DP2M DIKTI-LEMLIT UNM.

Rais, Muh. (2010). Project-Based Learning: Inovasi Pembelajaran Yang Berorientasi Soft Skills. Makalah Pendamping dalam Seminar Nasional Pendidikan Teknologi dan Kejuruan Fakultas Teknik Universitas Negeri Surabaya

Rosenfeld, Sherman; Benhur, Yehuda. (2001). Project-Based Learning (PBL) In Science and Technology: A Case Study of Professional Development. Journal of Action Research and Professional Development. Volume II. Page 460-480. 
Sukarno, Permanasari, A., \& Hamidah, I. (2013). Science Teacher Understanding to Science Process Skills and Implications for Science Learning at Junior High School (Case Study in Jambi). International Journal of Science and Research (IJSR), 2(6), 450-454.

Tasiwan. (2015). Efek Pembelajaran Berbasis Proyek Terbimbing terhadap Perkembangan Keterampilan Proses dan Sikap Sains Siwa. Berkala Fisika Indonesia, 7(2), 39-48.

Widyaningsih, S.W dan I. Yusuf. (2016). Keterampilan Proses Sains Mahasiswa Melalui Penggunaan Media Laboratorium Virtual Pada Mata Kuliah Fisika Dasar Universitas Papua. Pancaran, Vol. 5, No. 3, hal 99-110.

Yennita, MugiSukmawati, dan Zulirfan. (2012). Hambatan Pelaksanaan Praktikum IPA Fisika yang Dihadapi Guru SMP Negeri di Kota Pekanbaru. Jurnal Pendidikan, 3(1): $1-11$. 